\title{
Relationship between diet and smoking-Is the diet of smokers different?
}

\author{
J E Cade, B M Margetts
}

\begin{abstract}
Study objective-The aim was to compare nutrient intakes of smokers, past smokers, and non-smokers.

Design-The study was cross sectional and compared nutrient intake by smoking status using data obtained from a concurrent study of diet.

Setting-The study took place in three towns in England: Ipswich, Wakefield, and Stoke on Trent.

Participants-Food records were obtained from 1115 men and 1225 women aged 35 to 54 years, representing response rates of $84-86 \%$ in the three towns.

Measurements and main results-Diet was assessed using a $24 \mathrm{~h}$ food record in household measures. For both men and women vitamin $C$, total fibre, $\beta$ carotene, and vitamin $E$ intakes were lowest in the current smokers and highest in the nonsmokers with past smokers having intermediate values. Polyunsaturated/ saturated fat ratio was lowest in the current smokers. Men who smoked had higher energy intakes than those who did not. The lower fat intakes of $\beta$ carotene, vitamin $C$, fibre, and polyunsaturated fat in the smokers was due to fewer smokers eating a whole range of foods including fruit, wholemeal bread, cereals, and polyunsaturated margarine. Current smokers had a lower body mass index than nonsmokers or past smokers despite their higher energy intakes.

Conclusions-Smokers have different nutrient and food intakes compared with past smokers or non-smokers.
\end{abstract}

Community Medicine, Southampton General Hospital, Southampton, United Kingdom

J E Cade

Department of

Human Nutrition,

University of

Southampton,

Highfield,

Southampton, United

Kingdom

B M Margetts

Correspondence to:

Dr Cade, at Department of

Public Health Medicine,

University of Leeds, $20 \mathrm{Hyde}$

Terrace, Leeds LS2 9LN,

Terrace, Leeds
United Kingdom

Accepted for publication January 1991
Smokers develop more cancers of the lung, mouth, throat, pancreas, kidney, and urinary tract, and suffer more from coronary heart disease than do non-smokers. ${ }^{1}$ Apart from the smoking habit itself, other characteristics of smokers may increase their risk for these diseases. ${ }^{2}$ It has been suggested that some nutrients with antioxidant properties such as $\beta$ carotene, vitamin $C,{ }^{3}$ and vitamin $\mathrm{E}^{4}$ may be protective against cancer. It may be that higher rates of cancers in smokers could partly be explained by their lower intakes of these vitamins. It may also be that smokers have lower intakes of other nutrients, such as polyunsaturated fatty acids, which may be involved in the higher rates of coronary heart disease seen in smokers.

In our recent study of diet in 2340 men and women in three towns in England smoking habits were assessed. Here we contrast nutrient intakes of current, past, and non-smokers.

\section{Methods}

These have been described in detail elsewhere. ${ }^{5}$ In summary, approximately 400 men and 400 women aged 35 to 54 years selected from general practitioner lists in each of three towns, Ipswich, Wakefield, and Stoke on Trent, were surveyed. These towns were chosen to reflect the different geographical and socioeconomic characteristics of England.

Subjects were sent a $24 \mathrm{~h}$ dietary record to be completed on a specified day, with food intake to be recorded in household measures. Each day of the week and each season of the year was included. Subjects also completed a questionnaire concerned with various lifestyle characteristics including smoking. An interviewer checked the record and where a food record had not been completed a $24 \mathrm{~h}$ recall was taken of the previous day's intake.

Nutrient intakes were derived from food consumption using computerised food composition tables. ${ }^{6-8}$ Where intakes were not normally distributed they were transformed either to square roots or to logarithms.

\section{Results}

Food records were obtained from 2340 subjects (1115 men and 1225 women) representing response rates of $86 \%$ in Ipswich, $85 \%$ in Stoke, and $84 \%$ in Wakefield among those who could be contacted. Current and past smokers were defined as people who were smoking or had smoked at least once a day. Forty six percent of men and $35^{\%}$ o of women were found to be current smokers and $27 \%$ of men and $17 \%$ of women were past smokers. The current and past smokers included those who smoked cigarettes or cigars or who used tobacco in home made cigarettes or a pipe. Among the past smokers men and women had given up on average 11 years ago (SD 8 years, range $<1-33$ ). The main type and amount of tobacco smoked by current and past smokers is shown in table I. Among the men rather more past smokers $\left(86^{\circ}{ }_{0}\right)$ than current smokers $(69 \%)$ smoked mainly cigarettes. Twenty six per cent of current male smokers mainly used tobacco in home made cigarettes or a pipe, compared with $10 \%$ of past male smokers. Of the women, $99 \%$ smoked mainly cigarettes for both past and current smokers.

Results of selected nutrient intakes are presented in table II. There were no statistically significant differences between the towns for 
nutrient intakes according to non-smoking, past smoking, or current smoking status, and therefore the results from the three towns have been combined. Differences in nutrient intake between the non-, past, or current smoking groups were tested using a one way analysis of variance.

Energy intakes were significantly higher in current smokers than in non-smokers or past smokers among the men but not among the women. Men who smoked tended to eat more fat and carbohydrate than non-smokers. In men, the percentage of energy from protein was $14 \%$, from carbohydrate $46 \%$, and from fat $37 \%$. There were no differences between smokers and non-smokers apart from the percentage of energy from fat, which was slightly lower in the current smokers $(36 \%)$ and higher in the non-smokers $(38 \%)$. In women the percentage of energy from protein was similar for current smokers $(15 \%)$ and for nonsmokers and past smokers $(16 \%)$. The percentage of energy from carbohydrate $(46 \%)$ and from fat $(38 \%)$ in women was similar for the smokers and non-smokers. For both men and women, total fibre, vitamin $C, \beta$ carotene, and vitamin $E$ intakes were lowest in the current smokers and highest in

Table I Main type and amount of tobacco smoked

\begin{tabular}{|c|c|c|c|c|c|c|c|}
\hline & \multirow[b]{3}{*}{$n$} & \multicolumn{6}{|c|}{ Main type of tobacco smoked } \\
\hline & & \multicolumn{2}{|c|}{ Cigarettes } & \multicolumn{2}{|l|}{ Cigars } & \multicolumn{2}{|l|}{ Tobacco } \\
\hline & & Percent & $\begin{array}{l}\text { Average No } \\
\text { smoked/d }\end{array}$ & Percent & $\begin{array}{l}\text { Average No } \\
\text { smoked/d }\end{array}$ & Percent & $\begin{array}{l}\text { Average } \\
\text { ounces/week }\end{array}$ \\
\hline $\begin{array}{l}\text { Men: } \\
\text { Past smokers } \\
\text { Current smokers }\end{array}$ & $\begin{array}{l}302 \\
522\end{array}$ & $\begin{array}{l}86 \\
69\end{array}$ & $\begin{array}{l}21 \\
20\end{array}$ & $\begin{array}{l}4 \\
5\end{array}$ & $\begin{array}{l}7 \\
5\end{array}$ & $\begin{array}{l}10 \\
26\end{array}$ & $\begin{array}{l}3 \\
3\end{array}$ \\
\hline $\begin{array}{l}\text { Women: } \\
\text { Past smokers } \\
\text { Current smokers }\end{array}$ & $\begin{array}{l}208 \\
427\end{array}$ & $\begin{array}{l}99 \\
99\end{array}$ & $\begin{array}{l}13 \\
17\end{array}$ & & - & $\begin{array}{l}1 \\
1\end{array}$ & $\begin{array}{l}2 \\
2\end{array}$ \\
\hline
\end{tabular}

Table II Nutrient intake by smoking status. Values are means $\left(95^{\circ} \%\right.$ confidence intervals)

\begin{tabular}{|c|c|c|c|c|c|}
\hline \multirow[b]{2}{*}{ Nutrient } & \multirow{2}{*}{$\begin{array}{l}\text { Non- } \\
\text { smokers }\end{array}$} & \multirow{2}{*}{$\begin{array}{l}\text { Past } \\
\text { smokers }\end{array}$} & \multirow{2}{*}{$\begin{array}{l}\text { Current } \\
\text { smokers }\end{array}$} & \multicolumn{2}{|c|}{ One way ANOVA } \\
\hline & & & & $F$ & $p$ \\
\hline Energy (MJ) & $\begin{array}{l}\mathrm{n}=294 \\
10 \cdot 2\end{array}$ & $\begin{array}{l}\text { Men } \\
\mathrm{n}=305 \\
10.5\end{array}$ & $\begin{array}{l}\mathrm{n}=512 \\
11 \cdot 0\end{array}$ & 4.9 & 0.008 \\
\hline Total fat $(\mathrm{g})$ & $\begin{array}{l}(9 \cdot 8-10 \cdot 6) \\
101 \cdot 6\end{array}$ & $\begin{array}{l}(10 \cdot 1-10 \cdot 8) \\
102 \cdot 7\end{array}$ & $\begin{array}{l}(10 \cdot 7-11 \cdot 3) \\
104 \cdot 8\end{array}$ & 0.52 & 0000 \\
\hline $\mathrm{P} / \mathrm{S}$ ratio & $\begin{array}{l}(97 \cdot 0-106 \cdot 3) \\
0 \cdot 34\end{array}$ & $(97 \cdot 9-107 \cdot 5)$ & $(100 \cdot 7-108 \cdot 9)$ & & \\
\hline & $(0.31-0.36)$ & $\begin{array}{l}0.35 \\
(0.33-0.37)\end{array}$ & $\begin{array}{l}0.30 \\
(0 \cdot 29-0 \cdot 32)\end{array}$ & $8 \cdot 0$ & 0.0004 \\
\hline Vitamin C (mg) & $\begin{array}{l}55 \cdot 2 \\
(50 \cdot 2-60 \cdot 5)\end{array}$ & $\begin{array}{l}52.3 \\
(47.6-57 \cdot 2)\end{array}$ & $\begin{array}{l}47.7 \\
(44 \cdot 2-51 \cdot 4)\end{array}$ & $3 \cdot 1$ & 0.05 \\
\hline$\beta$ Carotene $(\mu \mathrm{g})$ & 1071 & $\begin{array}{l}909 \\
(766-1080)\end{array}$ & $\begin{array}{l}728 \\
(638-831)\end{array}$ & $6 \cdot 2$ & 0.002 \\
\hline Retinol ( $\mu \mathbf{g})$ & $\begin{array}{l}472 \\
(430-518)\end{array}$ & $500-1080)$ & $\begin{array}{l}(038-831) \\
472-512)\end{array}$ & 0.5 & 0.6 \\
\hline Vitamin E (mg) & $\begin{array}{l}5 \cdot 4 \\
(5 \cdot 1-5 \cdot 8)\end{array}$ & $\begin{array}{l}(450-556) \\
5.3\end{array}$ & $\begin{array}{l}(434-512) \\
4.8\end{array}$ & $4 \cdot 6$ & 0.01 \\
\hline Total fibre (g) & $\begin{array}{l}(5 \cdot 1-5 \cdot 8) \\
20 \cdot 6 \\
(19 \cdot 5-21 \cdot 8)\end{array}$ & $\begin{array}{l}(5 \cdot 0-5 \cdot 7) \\
19 \cdot 9 \\
(18 \cdot 9-20 \cdot 9)\end{array}$ & $\begin{array}{l}(4 \cdot 6-5 \cdot 1) \\
17.5 \\
(16 \cdot 7-18 \cdot 3)\end{array}$ & $13 \cdot 2$ & 0.0000 \\
\hline Energy (MJ) & $\begin{array}{l}n=574 \\
6.8\end{array}$ & $\begin{array}{l}\text { Women } \\
\mathrm{n}=213 \\
6.7\end{array}$ & $\begin{array}{l}n=427 \\
7 \cdot 1\end{array}$ & $2 \cdot 1$ & 0.1 \\
\hline Total fat (g) & $\begin{array}{l}(6 \cdot 6-7 \cdot 0) \\
69 \cdot 8\end{array}$ & $\begin{array}{l}(6 \cdot 3-7 \cdot 0) \\
68 \cdot 1\end{array}$ & $(6 \cdot 8-7 \cdot 3)$ & & 0.1 \\
\hline$P / S$ ratio & $\begin{array}{l}69 \cdot 8 \\
(67 \cdot 2-72 \cdot 5)\end{array}$ & $\begin{array}{l}68 \cdot 1 \\
(63 \cdot 8-72 \cdot 5)\end{array}$ & $\begin{array}{l}7 \cdot 4 \\
(68 \cdot 3-74 \cdot 6)\end{array}$ & 0.8 & 0.5 \\
\hline & $\begin{array}{l}0.32 \\
(0.30-0.33)\end{array}$ & $\begin{array}{l}0.34 \\
(0.31-0.36)\end{array}$ & $\begin{array}{l}0.29 \\
(0.28-0.31)\end{array}$ & 3.9 & 0.02 \\
\hline Vitamin C (mg) & $\begin{array}{l}49 \cdot 3 \\
(46 \cdot 1-52 \cdot 6)\end{array}$ & $\begin{array}{l}47 \cdot 6 \\
(42 \cdot 4-53 \cdot 2)\end{array}$ & 41.7 & $5 \cdot 0$ & 0.007 \\
\hline$\beta$ Carotene $(\mu \mathbf{g})$ & & & $\begin{array}{l}(38 \cdot 3-45 \cdot 2) \\
667\end{array}$ & 5.9 & 0.003 \\
\hline Retinol $(\mu \mathrm{g})$ & $\begin{array}{l}(820-1040) \\
389\end{array}$ & $\begin{array}{l}(640-949) \\
351\end{array}$ & $\begin{array}{l}(575-774) \\
320\end{array}$ & $4 \cdot 2$ & 0.02 \\
\hline Vitamin E (mg) & $\begin{array}{l}(354-427) \\
4 \cdot 1\end{array}$ & $\begin{array}{l}(304-406) \\
3.9\end{array}$ & $\begin{array}{l}(292-350) \\
3 \cdot 5\end{array}$ & 7.9 & 0.0004 \\
\hline Total fibre (g) & $\begin{array}{l}(3 \cdot 9-4 \cdot 3) \\
15 \cdot 2 \\
(14 \cdot 6-15 \cdot 8)\end{array}$ & $\begin{array}{l}(3 \cdot 6-4 \cdot 2) \\
14 \cdot 6 \\
(13 \cdot 7-15 \cdot 6)\end{array}$ & $\begin{array}{l}(3 \cdot 3-3 \cdot 7) \\
13 \cdot 1 \\
(12 \cdot 5-13 \cdot 7)\end{array}$ & $12 \cdot 1$ & 0.0000 \\
\hline
\end{tabular}

ANOVA $=$ analysis of variance the non-smokers, with past smokers having intermediate values. The ratio of polyunsaturated fat to saturated fat $(\mathrm{P} / \mathrm{S}$ ratio) was lowest in the current smokers, and retinol in the women was lowest in the current smokers.

The lower intakes of $\beta$ carotene, vitamin $C$, fibre, and polyunsaturated fat in the smokers was not due to a lower consumption of any one particular food, but rather to fewer smokers eating a whole range of foods containing these nutrients. In general fewer smokers recorded eating fruit of any kind. Fewer smokers ate wholemeal bread or cereals of any kind and fewer smokers used a polyunsaturated margarine than non-smokers or past smokers. In general portion sizes were similar between the groups. However, not only did more smokers use sugar and drink beer but they also consumed larger amounts than the non-smokers and past smokers.

Since smoking habits are affected by social class, this was taken into account in a further analysis of variance with social class as a covariate. Apart from vitamin $C$ intake in men, there was still, after adjusting for social class, a significant effect of smoking on total fibre, $\beta$ carotene, and vitamin $\mathrm{E}$ intakes in men and women, on vitamin $C$ intake in women, and on energy intake in men.

Body mass index was also measured and is shown by smoking habit in table III. Men and women who were current smokers had lower body mass indices than non-smokers or past smokers. Among men, the past smokers had the highest body mass index.

Table III Body mass index by smoking habit. Values are means ( $95 \%$ confidence interval)

\begin{tabular}{lll}
\hline & Men & Women \\
\hline Non-smokers & $26 \cdot 1$ & $26 \cdot 2$ \\
Past smokers & $(25 \cdot 5-26 \cdot 7)$ & $(25 \cdot 5-26 \cdot 8)$ \\
Current smokers & $26 \cdot 5$ & $26 \cdot 2$ \\
& $(26 \cdot 1-26 \cdot 9)$ & $(25 \cdot 3-27 \cdot 1)$ \\
& $25 \cdot 6$ & $24 \cdot 9$ \\
& $(25 \cdot 3-26 \cdot 0)$ & $(24 \cdot 5-25 \cdot 4)$ \\
\hline
\end{tabular}

\section{Discussion}

This is the first large study of diet in different parts of England which has looked at differences in nutrient intake between current, past, and non-smokers for both men and women. We found that current smokers, both men and women, had lower dietary intakes of $\beta$ carotene, vitamin $C$, total fibre, and vitamin $\mathrm{E}$, and a lower $\mathrm{P} / \mathrm{S}$ ratio than non-smokers or past smokers. A previous study by Fehily et $a l^{9}$ in men from South Wales also found that current smokers had lower dietary intakes of $\beta$ carotene, vitamin $C$, and total fibre than non-smokers, although there was no difference in energy intake. Another study of men from Scotland found that smokers had lower fibre intakes and a lower $\mathrm{P} / \mathrm{S}$ ratio than non-smokers but there were no differences in energy intake. ${ }^{10}$ Wood et $a l^{11}$ found that smokers had lower dietary intakes of polyunsaturated fatty acids than non-smokers. The recent study of diet in a national sample of British adults ${ }^{12}$ found that smokers had lower intakes of total fibre and vitamin $\mathrm{C}$ than non-smokers among both men and women. $\mathrm{P} / \mathrm{S}$ ratio and energy intakes were also 
lower among smokers than among non-smokers but the results were only statistically significant for the $\mathrm{P} / \mathrm{S}$ ratio of the men and for the energy intake of the women. The analysis did not separate past smokers from non-smokers.

The lower nutrient intakes of the smokers may be related to the higher rates of cancer and heart disease seen among smokers. The effect of the lower nutrient intakes may be compounded by the higher requirement for vitamin $C^{13}$ and $\beta$ carotene ${ }^{2}$ in smokers than in non-smokers. This may be due to smokers having a higher metabolic turnover for the nutrients than non-smokers. A case-control study of diet in women with either oral or pharyngeal cancer showed a protective effect of a usual diet high in fruit and vegetables and in bread and cereals when stratified by smoking habits. It was suggested that vitamin C could act as an anticancer agent by inhibiting nitrosamine formation, and that dietary fibre may cleanse the mouth and throat of ingested carcinogens. ${ }^{14}$ Besides their role in preventing nitrosamine formation vitamins $\mathrm{C}$ and $\mathrm{E}$ may also protect against cancer by their antioxidant function. ${ }^{4} \beta$ Carotene and vitamin $\mathrm{E}$ may exert their protective effect by acting as free radical scavengers.

$\beta$ Carotene intake has been found to be associated with lung cancer. However, a review of this subject ${ }^{15}$ has highlighted problems in many studies due to inappropriate adjustment for confounding resulting from the association between tobacco smoking and lung cancer. A recent meta-analysis of cigarette smoking and altered serum lipid concentrations showed that smokers had different cholesterol, triglyceride, and lipoprotein concentrations to non-smokers. ${ }^{16}$ This could explain some of the excess risk of heart disease among smokers and it was suggested that dietary differences could be involved. Some of the dietary differences found in our study would tend to increase cholesterol and triglycerides in the smokers.

Patterns of food intake similar to our study were seen in an analysis using the Health and Lifestyle Survey. ${ }^{17}$ For example, smokers ate fresh fruit less often and fried food more often than nonsmokers, ex-smokers, or occasional smokers. Fewer smokers ate breakfast and fewer smokers ate brown bread than white bread. The different patterns of eating behaviour between smokers and non-smokers or past smokers may reflect different personality types or the effect of smoking on taste. It is likely that those who continue to smoke have less regard for their health, including their diet, than those who have never smoked or who have given up the habit.
The body mass index in our study was lower in smokers than in non-smokers, in agreement with other studies. ${ }^{918}$ The fact that smokers had reported higher energy intakes than the nonsmokers may suggest that smoking increases metabolic rate ${ }^{19}$ or that smokers were less reluctant to report consumption of high energy foods than non-smokers.

In a cross sectional study such as ours, it is not possible to assess whether smoking is causally related to the lower consumption of nutrients that we observed. What is required is a study of the effect of stopping cigarette smoking on dietary habits, blood fatty acids, and subsequent risk of disease.

1 Royal College of Physicians of London. Smoking or health? London: Pitman Medical Publishing, 1977.

2 Stryker WS, Kaplan LA, Stein EA, Stampfer MJ, Sober A, Willett WC. The relation of diet, cigarette smoking, and alcohol consumption to plasma beta-carotene and alphatocopherol levels. Am f Epidemiol 1988; 127: 283-96.

3 Peto R, Doll R, Buckley JD. Sporn MB. Can dietary $\beta$-carotene materially reduce human cancer rates? Nature 1981; 190: 201-8.

4 Newberne PM, Suphakarn V. Nutrition and cancer: a review with emphasis on the role of vitamins $\mathrm{C}$ and $\mathrm{E}$ and selenium. Nutr Cancer 1983; 5: 107-19.

5 Cade JE, Barker DJP, Margetts BM, Morris JA. Diet and inequalities in health in three English towns. $B M F$ 1988; 296: 1359-62.

6 Paul AA, Southgate DAT. McCance and Widdowson's The composition of foods. 4th ed. London: HMSO, 1978.

7 Paul AA, Southgate DAT, Russel J. First supplement to Paul AA, Southgate DAT, Russel J. First supplement to
McCance and Widdowson's The composition of foods. London: HMSO, 1980.

8 Wiles SJ, Nettleton PA, Black AE, Paul AA. The nutrient composition of some cooked dishes eaten in Britain: a supplementary food composition table. F Hum Nutr 1980; 34: 189-223.

9 Fehily AM, Phillips KM, Yarnell JWG. Diet, smoking, social class and body mass index in the Caerphilly Heart Disease Study. Am $₹$ Clin Nutr 1984: 40: 827-33.

10 Fulton M, Thomson M, Elton RA, Brown S, Wood DA, Oliver MF. Cigarette smoking, social class and nutrient intake: relevance to coronary heart disease. Eur 7 Clin Nutr 1988; 42: 797-803.

11 Wood DA, Riemersma RA, Butler S, et al. Linoleic and eicosapentaenoic acids in adipose tissue and platelets and risk of coronary heart disease. Lancet 1987; i: 177-83.

12 Gregory J, Foster K, Tyler H, Wiseman M. The dietary and nutritional survey of British adults (Office of Population Censuses and Surveys). London: HMSO, 1990.

13 Kallner AB, Hartmann D, Hornig DH. On the requirements of ascorbic acid in men: steady state turnover and body pool in smokers. Am $\mathcal{F}$ Clin Nutr 1981; 34: 1347-55.

4 Winn DM, Ziegler RG, Pickle LW, Gridley G, Blot WJ, Hoover RN. Diet in the etiology of oral and pharyngeal cancer among women from the Southern United States. cancer among women from the

15 Palgi A. Vitamin A and lung cancer: a perspective. Nutr Palgi A. Vitamin A and

16 Craig WY, Palomaki GE, Haddow JE. Cigarette smoking and serum lipid and lipoprotein concentrations: an analysis of published data. $B M \mathcal{F}$ 1989; 298: 784-8.

17 Whichelow MJ, Golding JF, Treasure FP. Comparison of some dietary habits of smokers and non-smokers. $\mathrm{Br} \mathcal{F}$ Addict 1988; 83: 295-304.

18 Goldbourt U, Medalie JH. Characteristics of smokers, non-smokers and ex-smokers among 10,000 adult males in Israel. Am 7 Epidemiol 1977; 105: 75-86.

19 Wack JT, Rodin J. Smoking and its effect on body weight and the systems of caloric regulation. Am $\mathcal{F}$ Clin Nutr 1982; 35: $366-80$. 